\title{
Suitability of Natural Gravels in Ghana for Otta Seal Construction
}

\author{
Y. A. Tuffour ${ }^{1}$, A. Braimah ${ }^{2}$ \\ ${ }^{I}$ Civil Engineering Department, Kwame Nkrumah University of Science and Technology, Kumasi, Ghana \\ ${ }^{2}$ Department of Feeder Roads, Kumasi, Ghana
}

\begin{abstract}
Otta seals are bituminous chip seals constructed to upgrade low-volume gravel roads to surfaced standards using natural gravel or crushed rock containing some amount of fines for the seal coat. Currently, the Department of Feeder Roads in Ghana is piloting Otta seal field trials as a precursor to a more extensive application of the technology nationwide. However, the success of the application will depend on the availability of natural gravel of the required quality to support the construction. This study evaluated natural gravel samples from over 150 gravel deposits distributed throughout Ghana to establish their suitability for Otta seal construction. Particle size distribution, strength of the coarse particles, and the plasticity of the fines were used to assess the gravels in line with Otta seal requirements. Most (about 80\%) of the gravels met strength requirements measured by the 10\% Fines Value (both dry and wet) but failed Otta seal grading and Atterberg limits requirements. However, after the gravels had been screened to remove out-of-specification sizes and reduce the quantities of fractions with excessive contents, about $75 \%$ met Otta seal requirements. On average, screening did not result in more than $32 \%$ wastage in gravel quantity. It is recommended that the amount of gravel wastage must be factored into the cost of materials for costing of the construction.
\end{abstract}

Keywords: - Low-Volume Roads, Natural Gravel, Otta Seal, Screening, Suitability

\section{INTRODUCTION}

About 65 percent of the over $63,000 \mathrm{~km}$ of roads in Ghana are made up of low-volume roads, most classified as feeder roads with over 95 percent having natural gravel surfacing. Feeder roads are roads which connect rural communities and settlements to major roads and towns. They are important in supporting the socio-economic growth and development of rural communities in the country and are a key component of rural poverty reduction strategies being pursued by the government. They facilitate access to food production centres and the transportation of agricultural produce to markets. They also promote social inclusion for rural communities by providing access to towns, employment and social services. It is, therefore, important that such roads are well maintained to ensure all-weather and all-year use by the communities. But gravel roads present particular maintenance difficulty to road agencies in the country because of the need for periodic re-gravelling to restore gravel lost to traffic action and rainfall. In areas of the country where rainfall is heavy and prolonged, gravel loss and development of deep erosion gullies may be so rapid that a newly-constructed or rehabilitated gravel road could be rendered impassable just after one season of rains, unless there are timely maintenance interventions.

Early deterioration of gravel roads puts a high demand on the limited maintenance resources of road agencies, reduces access to a level that severely curtails social and economic development, and can put lives at risk in rural communities [1]. It is estimated that the average cost of periodic re-gravelling operations for gravel roads in many developing countries lies between US $\$ 500$ and US $\$ 2,000$ per $\mathrm{km}$ per year [2]. When a large gravel road network is involved, it requires a great deal of resources and institutional capacity to undertake regravelling operations. Aside maintenance costs, there are also concerns about gradual gravel resource depletion and environmental degradation associated with mining of gravel from deposits to replenish gravel lost on roadways. To minimize these concerns, unpaved or gravel roads may be upgraded by bituminous surfacing to reduce gravel loss and prolong the life of the roads. However, because most feeder roads carry very little traffic (in most cases substantially less than 50veh/day), their upgrade, using conventional chip seals, is generally not economically justified by the level of traffic [3]. This requires consideration of low-cost surfacing options such as Otta seals.

Otta seals are bituminous chip seals constructed using graded natural gravel or crushed rock containing some amount of fines for the seal coat. The technology is considered the most economical for surfacing lowvolume roads that carry less than 500veh/day [3]. The quality requirements for Otta seal aggregates are so flexible that they allow a wide range of aggregate sources and types to be used [4]. This flexibility makes it possible for many natural gravels within the proximity of a road under construction to be processed for use, thereby, cutting down on construction costs associated with materials and their haulage. 
In Ghana, natural gravels have for a long time been used as a road building material because of their wide availability and low cost. It is these reasons which have provided the motivation and economic incentive for the Department of Feeder Roads to consider using Otta seal technology to upgrade low-volume gravel roads under its jurisdiction. Currently, the Department is piloting Otta seal field trials in some parts of the country as a precursor to a more extensive application of the technology nationwide. The sustainability of the Otta seal technology in Ghana is seen to be linked not only to the successful performance of the trials and gravel availability but also gravel suitability. Even though extensive studies (e.g.[5]) have been undertaken in the past on the engineering characteristics and behaviour of natural gravels in the country, these have centred mainly on the use of the material as a structural component of road pavements. This study evaluated the suitability of natural gravels in Ghana for Otta seal construction.

\section{NATURAL GRAVELS IN GHANA}

According to Gidigasu [6], natural gravels in Ghana are usually a mixture of quartz and laterite particles in a matrix of fines and are recognised by their distinct red and ochre colour due to the presence of oxides of iron in the soils. Laterites are insoluble precipitates derived from the concentration of sesquioxides into concretions when moisture is lost from soils. Thus, depending on the proportion of quartz and laterite present, natural gravel may be called lateritic or quartzitic gravel. Gravels containing a high proportion of quartz particles (above 50\%) are termed quartzitic and those with over 50\% laterite particles are termed lateritic. Lateritic gravel formation in Ghana is favoured by the availability of sesquioxide-rich parent materials, high annual rainfall, the existence of acidic or neutral soil conditions, good soil permeability and alternating wet and dry seasons [6]. Thus, lateritic gravels are found over all rock types in the country and, therefore, are widely distributed. They are reddish in colour, characterised by concretionary particles, have variable texture, tend to be poorly-graded with deficiency in the sand fraction, and may have a fines content that may approach $40 \%$ with very high plasticity values.

Quartzitic gravels, on the other hand, are the residual soils derived from the weathering and decomposition of rocks that have quartz as the main component. Therefore, quartzitic gravels are found over quartzite, granite, pegmatite and other quartz-rich rocks. In Ghana, the gravels are limited mostly to the Eastern, Central, Volta and Greater Accra Regions where the geology is dominated by quartzitic rocks forming part of the regional geology referred to as the Togo Series [7]. The gravels have a granular texture, are generally well-graded with fines content of between $5 \%$ and $25 \%$.

\section{OTTA SEAL REQUIREMENTS}

Three major items form the basis for judging the suitability of natural gravels for Otta seals; these are

- Aggregate strength

- Particle size distribution

- Plasticity index of the fines component

\subsection{Aggregate Strength}

The 10\% Fines Value (for dry and wet conditions) is the only strength index used in assessing the quality of aggregates, with the minimum value dictated by the level of traffic at the time of construction (see Table 1).

Table 1. Aggregate strength and plasticity requirements [8]

\begin{tabular}{|l|c|c|}
\hline \multirow{2}{*}{ Material Property } & \multicolumn{2}{|c|}{ AADT (veh) } \\
\cline { 2 - 3 } & $<100$ & $>100$ \\
\hline $10 \%$ Fines Value, [Dry ] (kN) & $>90$ & $>110$ \\
\hline Wet/Dry Strength Ratio & $>0.60$ & $>0.75$ \\
\hline Plasticity Index (\%) & $<10$ & $<10$ \\
\hline
\end{tabular}

This lax requirement allows many local materials otherwise considered to have substandard strength for conventional chip seals to be used for Otta seals [9]. One possible reason for this quality relaxation is probably due to the fact that Otta seals are associated with roads carrying very low traffic and, therefore, the aggregates forming the seal coat are unlikely to be subjected to stresses that demand high strength.

\subsection{Particle Size Distribution}

The essential feature of the particle size distribution of aggregates for Otta seal is the wide range allowed for each particle size so that a variety of natural gravels can be processed and used for the construction (see Table 2). 
Table 2. General Aggregate Grading for Otta Seals [8]

\begin{tabular}{|c|c|}
\hline $\begin{array}{c}\text { Sieve Size } \\
(\mathbf{m m})\end{array}$ & \% Passing \\
\hline 19.0 & 100 \\
16.0 & $80-100$ \\
13.2 & $52-100$ \\
9.5 & $36-98$ \\
6.7 & $20-80$ \\
4.75 & $10-70$ \\
2.00 & $0-48$ \\
1.18 & $0-38$ \\
0.425 & $0-25$ \\
0.075 & $0-10$ \\
\hline
\end{tabular}

In the field, gravel materials are processed by removing over-size aggregates and excessive fines. Large aggregates generally do not bond and embed well in seal mats and, hence, are easily dislodged from their placement positions by traffic, leading to pothole development. Excessive fines are removed so as to reduce the plasticity of the soil and also improve the adhesion of binder to aggregate surfaces. The processing may also involve reducing the contents of fractions that are over-represented.

\subsection{Plasticity}

The plasticity of the fines content is not to exceed $10 \%$ irrespective of the level of traffic expected to use the road. This limit appears to be dictated by the need to minimise the clay content in order to reduce binder demand because such particles require high amounts of binder for wetting during bituminous construction due to their large surface area.

\subsection{Gravel Samples}

\section{MATERIALS AND METHODS}

A total of 158 gravel samples distributed throughout Ghana were considered in this study. These were made up of 37 primary samples and 121 secondary samples. In the context of this paper, primary samples were those taken directly from gravel pits by the research team while secondary samples were gravel samples that had been used on construction projects in the country whose source and engineering data were retrieved from project files within the regions. The primary samples were taken from the Northern, the Ashanti and the Central Regions to reflect the different types of gravel materials likely to be encountered in the country. Fig. 1 is a regional map of Ghana showing the distribution of some of the major gravel pit locations from which gravel samples (primary and secondary) were taken.

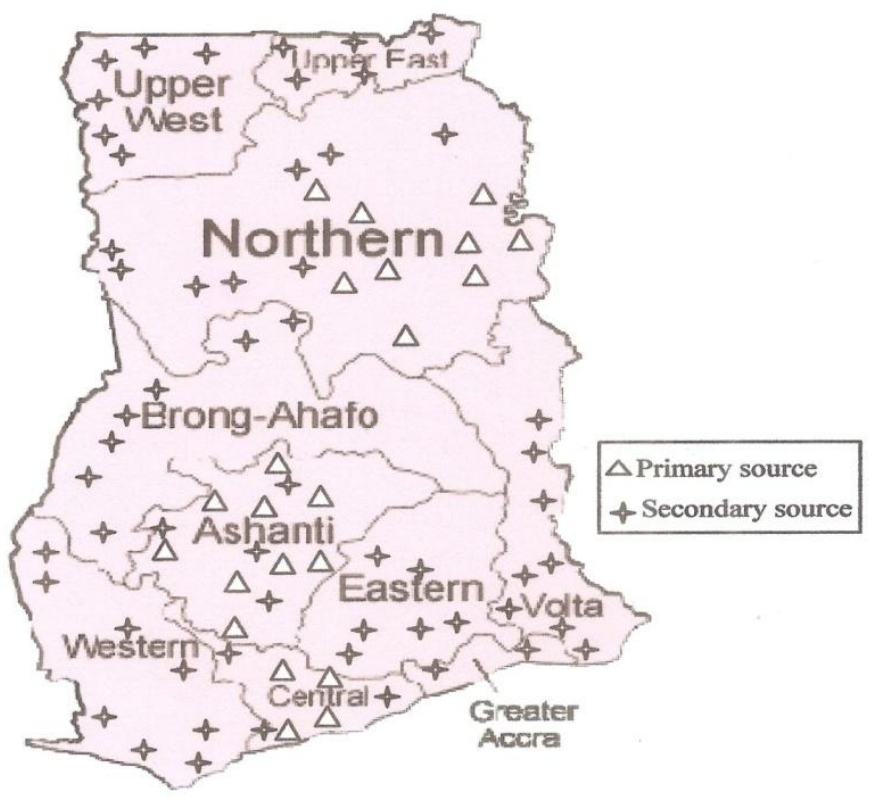

Fig. 1. Regional map of Ghana showing approximate locations of major gravel deposits 


\subsection{Grading Tests}

The particle size distribution of each soil material was determined using wet sieving method in accordance with BS 1377 [10] on representative portions of the primary gravel samples after the materials had been oven dried at $105^{\circ} \mathrm{C}$ for 24 hours. Grading information on the secondary samples was retrieved from project files.

\subsection{Screening}

Screening was used to bring the grading of the natural gravel samples to the grading of Otta seals and involved one or two cycles of processing. A representative sample was taken and its mass noted before it was subjected to a first cycle of screening purposely to remove out-of-specification size fractions, particularly materials retained on the $19 \mathrm{~mm}$ sieve and fines passing the $0.075 \mathrm{~mm}$ sieve. Materials that still did not meet the grading requirement after the first screening were subjected to a second screening to reduce the quantities of those size fractions whose content exceeded the specification range. The weight of material left was noted to provide an indication of the percentage of the original quantity wasted by the screening process.

\subsection{Strength Evaluation}

The 10\% Fines Test (wet and dry) was carried out on the primary samples using particles which passed the $14 \mathrm{~mm}$ sieve and were retained on the $10 \mathrm{~mm}$ sieve in accordance with BS 812 [11].

\subsection{Atterberg Limits Test}

The plastic and liquid limit tests were carried out in accordance with BS 1377 [10] on the fines fraction (below $0.425 \mathrm{~mm})$ of the primary samples.

\subsection{Gravel Types and Strength}

\section{RESULTS}

Table 3 contains summary information on the type and average strength (10\% Fines Value) of the primary samples. Of the 37 primary samples, 16 were quartzitic and 21 were lateritic. All the samples from the Northern Region were lateritic whereas those from the Central Region were quartzitic; the samples from the Ashanti Region consisted of both lateritic and quartzitic gravels.

Table 3. Summary of type and strength of primary gravel deposits sampled

\begin{tabular}{|c|c|c|c|c|c|c|c|}
\hline \multirow{2}{*}{$\begin{array}{c}\text { Sample } \\
\text { Source } \\
\text { (Region) }\end{array}$} & \multirow{2}{*}{$\begin{array}{l}\text { Gravel } \\
\text { Type }\end{array}$} & \multirow{2}{*}{$\begin{array}{c}\text { No. of } \\
\text { Deposit } \\
\quad s\end{array}$} & \multicolumn{2}{|c|}{$\begin{array}{l}\text { 10\% Fines } \\
\text { Value }(\mathbf{k N}) \\
\end{array}$} & \multirow{2}{*}{$\begin{array}{l}\text { Wet/Dr } \\
\text { y Ratio }\end{array}$} & \multicolumn{2}{|c|}{ \% Passing Requirement } \\
\hline & & & Dry & Wet & & $\begin{array}{c}\mathrm{AADT}<10 \\
0\end{array}$ & $\begin{array}{c}\text { AADT }>10 \\
0\end{array}$ \\
\hline Northern & Lateritic & 8 & 90 & 69 & 0.77 & 75.0 & 0.0 \\
\hline \multirow{2}{*}{ Ashanti } & Lateritic & 9 & 133 & 103 & 0.77 & 88.9 & 33.3 \\
\hline & Quartzitic & 8 & 113 & 88 & 0.78 & 75.0 & 37.5 \\
\hline Central & Quartzitic & 12 & 110 & 92 & 0.84 & 83.3 & 41.7 \\
\hline
\end{tabular}

Also contained in the table are the average strength values for both dry and wet conditions as well as the wet/dry strength ratios for the samples. The results show that at least $75 \%$ of the primary samples from each of the three regions satisfied the strength requirement for AADT less than 100 vehicles and only a little over $30 \%$ satisfied the requirement for traffic in excess of 100 vehicles per day; the only exception being samples from the Northern Region none of which satisfied the strength requirement for high traffic. In terms of quality measured by strength, there was no definite distinction between the two types of gravels, except that the laterite from the Northern Region tended to be slightly lower in strength than those from the other regions. Strength data and gravel types for the secondary samples were not available but were not expected to be different from those of the primary samples.

\subsection{Particle Size Distribution of Samples}

Figure 2 shows the particle size distribution curves of the primary and secondary samples superimposed on the Otta seal grading envelope. Detailed analysis of the individual data did not find any of the samples meeting the particle size distribution requirement for Otta seals as almost all samples contained either out-of-specification size fractions, particularly, coarse fractions above $19 \mathrm{~mm}$ and fines below $0.075 \mathrm{~mm}$ or had certain size fractions well above specification range or both. This is evidenced in Fig. 2 by the crowding of the grading curves above and the masking of the upper limit of the Otta seal grading envelope by the curves. 


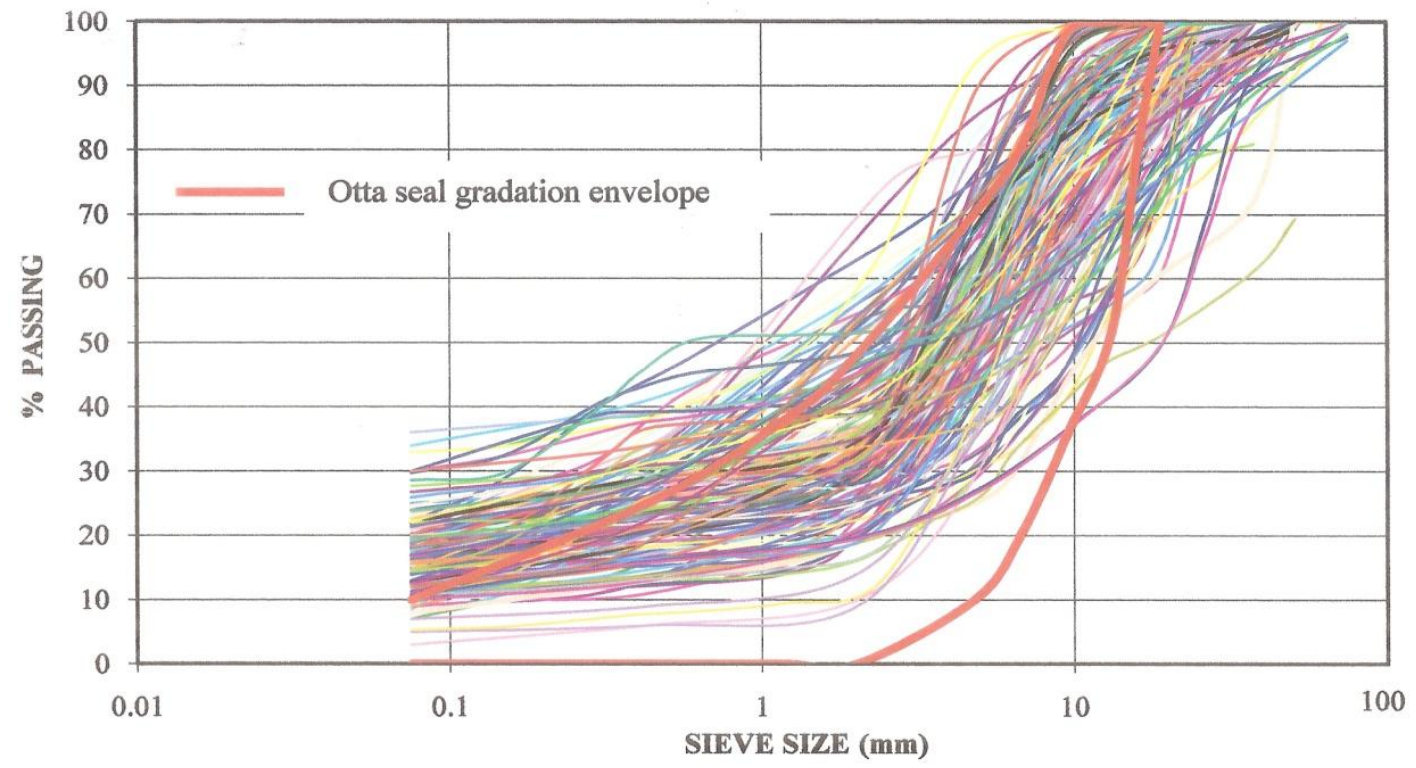

Fig. 2. Grading of gravel samples superimposed on Otta seal grading envelope.

\subsection{Plasticity Index of Gravels}

Table 4 contains the summarised data on the plasticity indices of the primary and secondary samples put together. As can be seen from the table, PI values ranged between $0 \%$ and $28 \%$ with only about $46 \%$ of the samples meeting the requirement of $\mathrm{PI}=10 \%$ or less. From the data summary, only gravel deposits in the Volta and Upper West Regions had very high proportions (about 90\%) of the samples meeting the plasticity requirement. Failure of most of the gravel samples in the country to meet the plasticity requirement may be attributed to high fines content (mostly above 15\%) in the clay size range.

Table 4. Summary of plasticity data on gravel samples from the regions

\begin{tabular}{|c|c|c|c|c|}
\hline \multirow{2}{*}{$\begin{array}{l}\text { Sample } \\
\text { Source } \\
\text { (Region) }\end{array}$} & \multirow{2}{*}{$\begin{array}{c}\text { No. of } \\
\text { Samples }\end{array}$} & \multicolumn{2}{|c|}{$\begin{array}{c}\text { PI Range } \\
(\%)\end{array}$} & \multirow[t]{2}{*}{$\begin{array}{l}\text { \% Passing } \\
\text { Requirement }\end{array}$} \\
\hline & & Low & High & \\
\hline Northern & 27 & 6 & 13 & 26 \\
\hline Upper West & 16 & 4 & 24 & 88 \\
\hline Upper East & 10 & 4 & 14 & 50 \\
\hline Ashanti & 29 & 4 & 28 & 38 \\
\hline Western & 19 & 3 & 22 & 42 \\
\hline Brong Ahafo & 16 & 0 & 19 & 50 \\
\hline Eastern & 4 & 16 & 20 & 0 \\
\hline Central & 26 & 4 & 19 & 35 \\
\hline Volta & 11 & 4 & 15 & 91 \\
\hline
\end{tabular}

\subsection{Properties of Screened Samples}

\subsubsection{Particle size distribution}

Figure 3 shows the particle size distribution curves for all the screened samples superimposed on the Otta seal grading envelope. 


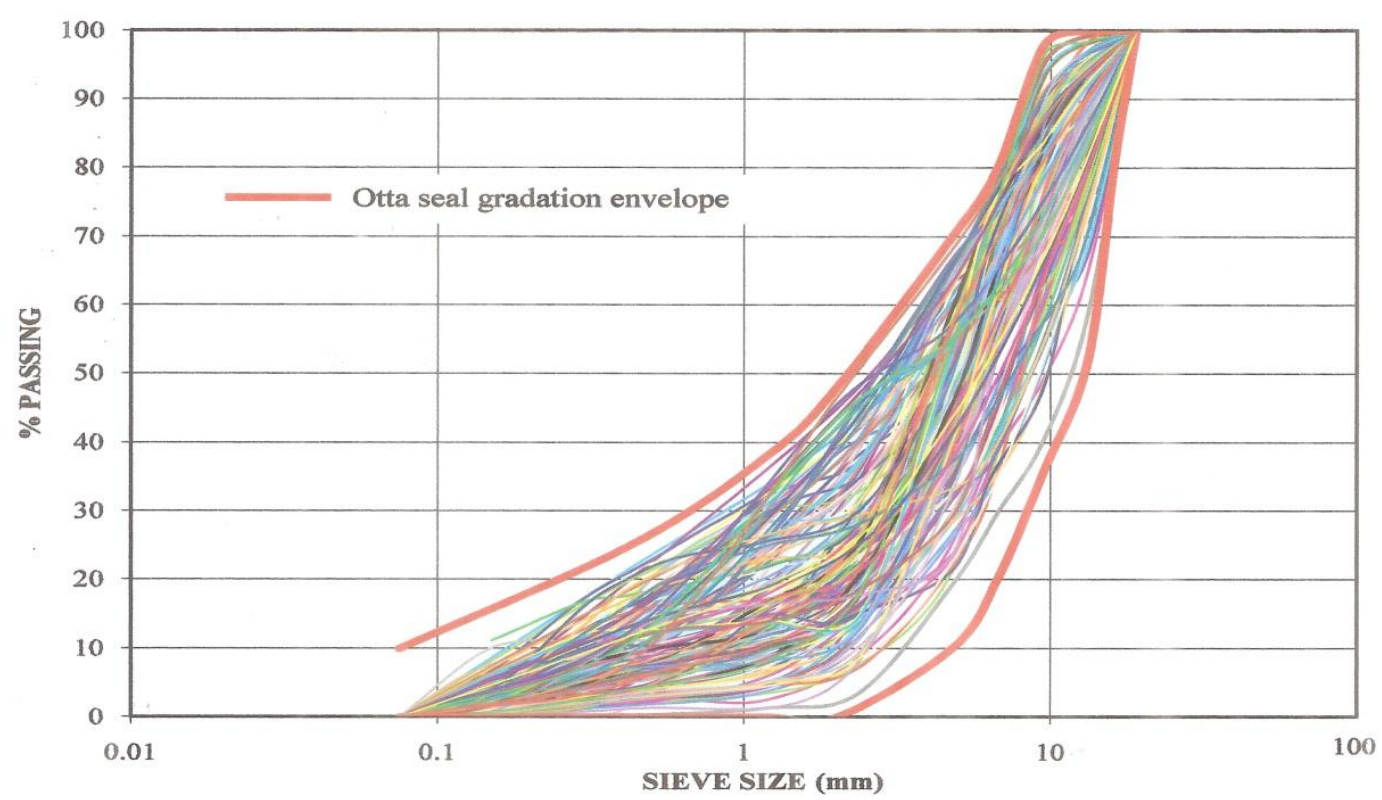

Fig. 3. Grading curves of screened gravels superimposed on Otta seal grading.

Majority of the entire samples (about 78\%) were subjected to only one cycle of screening, and the rest to two cycles in order to bring their particle size distribution in line with Otta seal grading. In the case of samples from the Northern Region, screening involved the removal of only the fine fractions below $0.075 \mathrm{~mm}$ since the samples did not have particle sizes above $19 \mathrm{~mm}$. The screening of gravel samples from the other regions involved removal of both larger particles (above 19mm) and fines (below $0.075 \mathrm{~mm}$ ). All the gravel samples from the Upper East Region went through two cycles of screening before meeting the grading requirement.

\subsubsection{Plasticity Index}

The plasticity test could not be carried out successfully on any of the screened products of the primary samples which failed the plasticity requirement in their natural state apparently because only non-plastic fines remained after all particles below $0.075 \mathrm{~mm}$ had been removed by screening. Table 5 summarises the average PI values of the samples before and after screening with the values for the screened samples reported as "nonplastic". The results were not unexpected as the fines screened out consisted of all the clay fractions (the fractions responsible for imparting plasticity characteristics to a soil), all the silt fractions and some amount of fine sand. Thus the fines left were essentially a mixture of only medium and fine sand which are obviously nonplastic.

Table 5. Average PI values of samples before and after screening

\begin{tabular}{|c|c|c|c|c|}
\hline \multirow{2}{*}{$\begin{array}{l}\text { Sample } \\
\text { Source } \\
\text { (Region) }\end{array}$} & \multirow[b]{2}{*}{$\begin{array}{l}\text { Gravel } \\
\text { type }\end{array}$} & \multirow{2}{*}{$\begin{array}{l}\text { No. of } \\
\text { Samples }\end{array}$} & \multicolumn{2}{|c|}{ Average PI (\%) } \\
\hline & & & $\begin{array}{l}\text { Before } \\
\text { screening }\end{array}$ & $\begin{array}{l}\text { After } \\
\text { screening }\end{array}$ \\
\hline Northern & Lateritic & 3 & 12 & Non-plastic \\
\hline \multirow{2}{*}{ Ashanti } & Lateritic & 8 & 21 & Non-plastic \\
\hline & Quartzitic & 7 & 19 & Non-plastic \\
\hline Central & Quartzitic & 9 & 14 & Non-plastic \\
\hline
\end{tabular}

\subsection{Gravel wastage from screening}

The quantity of gravel material reduces whenever the material is subjected to screening. In the case of the present study, it was important to establish the extent of material wastage arising from the screening process. Table 6 provides the regional summary of the average proportions of original gravel mass wasted after screening. 
Table 6. Average gravel wastage from screening

\begin{tabular}{|l|c|c|}
\hline $\begin{array}{c}\text { Sample Source } \\
\text { (Region) }\end{array}$ & $\begin{array}{c}\text { No. of } \\
\text { Samples }\end{array}$ & \% Mass wasted \\
\hline Northern & 27 & 28 \\
\hline Upper West & 16 & 20 \\
\hline Upper East & 10 & 49 \\
\hline Ashanti & 29 & 28 \\
\hline Western & 19 & 39 \\
\hline Brong Ahafo & 16 & 31 \\
\hline Eastern & 10 & 40 \\
\hline Central & 26 & 30 \\
\hline Volta & 11 & 41 \\
\hline
\end{tabular}

It is seen that whereas gravel samples from the Upper West Region suffered the least wastage (20\%), those from the Upper East suffered the most (49\%) from screening due to the fact that the latter had to be subjected to two cycles of screening. It must be noted though that some gravel deposits experienced wastage in mass far above the average values indicated in Table 6. For example, analysis of the screening data showed that about $40 \%$ of the samples from the Upper East and 30\% from the Eastern Region experienced more than 50\% wastage in quantity after screening. On the whole, it was noted that gravel deposits in regions where the local geology is dominated by quartzitic rocks tended to suffer high screening waste as such gravels often have a high amount of large size quartz particles present. Gravels from such deposits if used for Otta seal would add substantially to material costs. However, when the data for all the regions were aggregated for the country as a whole, screening did not result in more than an average of $32 \%$ wastage in gravel quantity.

\section{DISCUSSION}

This study has indicated that gravel samples in Ghana in their natural state do not meet Otta seal requirements. This was not unexpected as over representation or under-representation of certain size fractions and the possible presence of over-size fractions always cause natural gravels to deviate from either Otta seal grading or plasticity or both. This explains why screening of gravel materials before use is an integral part of every Otta seal construction. But once a gravel has been screened to remove the fines in the clay range, plasticity concerns are no more an issue. Even though screening is particularly helpful in reducing the silt and clay contents (materials which tend to require high amounts of bitumen for surface wetting in bituminous constructions), it has the disadvantage of reducing the quantity of gravel material available for use. For the gravels evaluated in this study, practically all needed screening, with some experiencing as much as over $40 \%$ reduction in quantity after the process.

As has been noted earlier, the appeal of Otta seals derives from the cost savings which result from the use of the natural gravels in the proximity of the construction. This benefit would be severely eroded if about $50 \%$ or more of the gravel were to be screened out before use. Wastage from screening must, therefore, be treated as supplementary information to the requirements for gravel suitability because of its cost implications. Fortunately, most of the gravel samples evaluated in this study did not require extensive screening to bring them in line with Otta seal requirements. Even where two cycles of screening had to be carried out, gravel wastage was tolerable. For the country as a whole, if the criterion was set to reject samples for which screening caused more than $50 \%$ gravel wastage, only $8 \%$ of the gravel deposits would be rejected and that would be limited mostly to deposits in the Upper East and Eastern Regions. On the whole, however, for most of the gravel samples, material wastage caused by screening did not amount to more than $32 \%$ of the original mass.

In terms of strength, most of the natural gravels on which the strength tests were conducted showed adequate strength, at least for AADT not exceeding 100 vehicles. In general, strength is unlikely to be an issue of concern for most natural gravel deposits in the country as geologically, the coarse fractions of gravelly soils tend to consist of fragments of hard rock or rocks that have quartz as the predominant mineral. For lateritic gravels, the concretionary particles present contain iron oxide compounds which make the gravelly fractions of such soils equally hard. That is why, as evidenced by the results in Table 3, no distinction could be made between the quartzitic and lateritic gravels in terms of strength. For the many gravel deposits in the country, it was only those in the Northern Region which did not meet the strength requirement for high traffic. However, this is not seen to present any setback to Otta seal construction in that region as that part of the country is among the least motorized regions where vehicular traffic in excess of 50 vehicles/day on low-volume roads is very unlikely; not even on market days. For the country as a whole, an AADT of 20-30 vehicles may characterise most low volume roads, doubling or tripling only on market days. Therefore, the strength values of the aggregates evaluated in this study are sufficiently satisfactory for Otta seal construction. 


\section{CONCLUSION}

The availability of natural gravel deposits throughout Ghana provides the motivation to use the Otta seal technology to upgrade low-volume roads to surfaced standard. However, gravel availability does not necessarily translate to material suitability for the seal. In this study a number of gravel deposits distributed throughout the country were evaluated to establish their suitability for Otta seal construction. Most (about 80\%) of the gravels in their natural state met only the strength requirement for Otta seal but deviated from the grading and plasticity requirements due, in most cases, to high contents of clay and oversize fractions. To be able to use them for Otta seal construction, the gravels require screening to reduce certain fractions, particularly the fines content and out-of-range fractions and/or remove oversize fractions, to bring the materials in line with Otta seal grading and plasticity requirements. The evaluation undertaken in this study showed that about $78 \%$ of the natural gravels in the country require only one cycle of screening to bring them to Otta seal grading. It was established that in terms of the total requirements, about $75 \%$ of the natural gravels in Ghana could be used for Otta seal construction when processed by screening. Even though screening is particularly helpful in reducing the silt and clay contents, it has the disadvantage of reducing the quantity of gravel material available for use. In general, however, when processed by screening, whether by one cycle or two cycles, most of the natural gravels in the country (about 92\%) are not expected to suffer more than $32 \%$ wastage in quantity. Material wastage from screening would add some element of cost to the construction which must not be overlooked.

\section{REFERENCES}

[1] C. Gourley, A. Greening, D. Jones, and R. Petts, Paving the Way for Rural Development \& Poverty Reduction. Presented at the 20th Conference of ASEAN Federation of Engineering Organisations (CAFEO 20), Phnom Penh, Cambodia, 2 - 4 September 2002. Available at http://www.transportlinks.org/transport_links/filearea/publications/1_803_PA\%203938-03.pdf

[2] R. Petts, Rationale for the Compilation of International Guidelines for Low-Cost sustainable Road Surfacing, Low-Cost Road Surfacing Project Working Paper No. 1, Intertech Associates, March 2002. Available at: http://www1.mt.gov.vn/gtnt2/05\%20PDF\%20Files/INTECH/Working\%20Paper1ha/Section\%201_ENG.pdf

[3] S. Oloo, R. Lindsay, and S. Mothilal, Otta Seals and Gravseals as Low-Cost Surfacing Alternatives for Low-Volume Roads: Experiences in South Africa, Transportation Research Record 1819B, 2003, pp 338-342.

[4] Transport Research Laboratory (TRL), Manual for the labour-based construction of bituminous surfacings on low-volume roads, Department for International Development, Crowthorne, UK, 2003.

[5] J. W. S De Graft-Johnson, H. S. Bhatia, and D. M. Gidigasu, The Engineering Characteristics of the Laterite Gravels of Ghana, Building and Road research Institute (BRRI), Kumasi, Ghana, 1969.

[6] D. M. Gidigasu, Mode of Formation and Geotechnical Characteristics of Laterite Materials of Ghana in Relation to Soil Forming Factors, Building and Road Research Institute (BRRI), Kumasi, Ghana, 1976.

[7] G. O. Kesse, The Mineral and Rock Resources of Ghana, 1985, A. A. Balkerma.

[8] C. Overby, A guide to the use of Otta Seals: Directorate of Public Roads, Publication No 93, Road Technology Department, August 1999, Oslo, Norway.

[9] P. Paige-Green, J. Hongve, L. Sampson, and I. Cassiem, Labour-based bitumen roads as cost-effective alternatives to conventional gravel wearing courses, $8^{\text {th }}$ Conference on Asphalt Pavements for Southern Africa (CASPA '04), 12-16 ${ }^{\text {th }}$ September, 2004. Sun City, South Africa.

[10] British Standards 1377 (1990): British Standards Institution, London.

[11] British Standards 812 (1990): British Standards Institution, London. 